\title{
Environmental taxes in ensuring national security: A structural optimization model
}

\author{
Yaryna Samusevych \\ Department of Accounting and Taxation, \\ Sumy State University, \\ Ukraine \\ y.samusevych@uabs.sumdu.edu.ua \\ Josef Maroušek \\ Institute of Technology and Business in Ceské Budèjovice, \\ Czech Republic \\ josef.marousek@gmail.com
}

\section{Olha Kuzmenko}

Department of Economic Cybernetic,

Sumy State University

Ukraine

o.kuzmenko@uabs.sumdu.edu.ua

\author{
Justas Streimikis \\ Lithuanian Centre for Social Sciences, \\ Institute of Economics and Rural Development, Vilnius, Lithuania \\ Faculty of Management and Finances, \\ University of Economics and Human Science in Warsaw, Poland \\ Justas.streimikis@gmail.com
}

\author{
Alina Vysochyna \\ Department of Accounting and Taxation, \\ Sumy State University, \\ Ukraine \\ a.vysochyna@uabs.sumdu.edu.na
}

Abstract. The purpose of the article is to assess the optimal ratio of environmental taxes in the context of national security. National security is defined as a complex parameter of indicators of economic, environmental and energy security, sensitive to the impact of environmental taxation, according to the method of Kolmogorov-Gabor. The environmental taxes with the greatest 
selected. The sample of the study consisted of six European countries (Belgium, France, Austria; Finland and United Kingdom). The study covers the time period between 1994-2019. The optimization model of the structure of environmental taxes, which provides maximization of the level of national security, is built using the simplex method and the method of the general reduced gradient. The calculations allowed determining the optimal structural ratios of environmental taxes within each country thatachieves the maximum level of integrated national security. Besides, the strategic guidelines for adjusting national environmental taxation systems were developed to ensure national security.

Keywords: environmental tax, environmental security, energy security, economic security, causality, optimization modelling.

JEL Classification: C43, E62, F52, H23

\section{INTRODUCTION}

Environmental sphere remains one of the crucial problems in the modern world community. The environmental sector requires sharp attention, as well as new and improved ways to ensure its effective functioning. The number of issues related to the need to be environmentally friendly is constantly growing due to the deteriorating impact of social processes and phenomena on the environment. Thus, environmental threats, such as depletion and destruction of available natural resources, pollution of the environment with artificial harmful substances, man-made disasters, environmental sabotage and others are very dangerous for further safe functioning of society (Chovancová, J., \& Tej, J. 2020; Didenko et al., 2020; Dkhili, 2018). All this is exacerbated by political, legal, economic and social factors: imperfection of the legal framework for environmental law, insufficient efficiency of nature protection systems, improper organization of state control over the activities of entities that pollute or may adversely affect the environment, national economic situation, insufficient funding of the environmental sector, inefficient system of environmental taxation, unconscious environmental culture of society and others (Eddassi, H. 2020; Formankovaa, et al., 2018; He, 2019; Lyulyov et al., 2021). In turn, environmental threats significantly affect the general situation of the country, its safe functioning, the ability of public authorities to promptly intervene in emerging environmental problems, make necessary decisions and take appropriate action to address them effectively, determine the ability of people to consciously assess the importance of the environment. and the need to protect the environment (Masharsky et al., 2018; Sibanda \& Ndlela, 2020; Starchenko et al., 2021; Vasylieva et al., 2021; Vysochyna et al., 2020b). Environmental security is closely linked to other types of national security, especially to the financial and economic sphere as one of the driving forces in ensuring overall national security and being able to provide adequate funding for the environmental protection through an effective system of measures, including environmental taxation. In turn, environmental taxes play a twofold role: on the one hand, a regulatory oneprovidings the ability to change the actions of those who harm the environment, and financially stimulate further rethinking and change of violators' behaviour, and on the other hand - a compensatory one, which will cover the damage and create a cushion of safety in case of possible economic and environmental losses. 


\section{LITERATURE REVIEW}

General theoretical issues of national security are revealed in the works of world scientists (Samusevych et al., 2021; Mentel et al., 2020; Kubaienko, 2018; Didenko et al., 2021; Didenko et al., 2020a). They reveal the concept of security, describe the category of national security, its types, components, indicators, methods of achieving state security, describe threatening factors, determinants, features of the shadow economy, threats of bureaucracy, corruption and other issues. The transition of the world economy to a new technological system requires special consideration of the impact of the innovative economy on national security and the achievement of sustainable development goals. This direction has opened up new horizons for measuring the national security of the state in the global context (Amrin \& Nurlanova, 2020; Kolosok et al., 2021; Lesakova, 2019; Medani, 2019; Mikhaylova et al., 2019). New challenges to national security have been created by the global Covid-19 pandemic. The first results of scientific research proved the existence of significant multiplicative links between certain areas of national security and testified to the need for its comprehensive study (Tiutiunyk et al., 2021; Antonyuk et al., 2021; Us et al., 2020).

Strong transmission effects are confirmed between social behavior and environmental security (Ahmed et al, 2019; Holotová et al., 2020; Vafaei et al., 2019) as well as entrepreneurial sustainable policy, which creates new prospects to enhance environmental and national security (Alimuddin et al., 2020; Atkociuniene \& Mikalauskiene, 2019; Nikodemska-Wołowik et al., 2019; Romana, 2020; Vasylieva et al., 2017). Studies of the relationship between different types of national security have shown that the closest interaction exists in the group "environmental-energy-economic security" (Atta Mills et al., 2020). Thus, energy and environmental security are connected through the structure of energy production (JonekKowalska, 2019; Kolosok et al., 2020), development of alternative energies (Cebula et al., 2018; Prokopenko et al., 2017), sustainable and green investment (Pavlyk, 2020). On the other hand, economic preconditions define the efficiency of environmental-energy interaction in terms of sustainable development strategies realizing (Cebula \& Pimonenko, 2015; Vasilyeva et al., 2020a; Petrushenko et al., 2017). Thus, the achieved high level of macroeconomic stability creates reserves for the progressive transformation of the national economy in the direction of more environmentally responsible, eliminating threats to economic and energy security (Bilan et al., 2020; Fomina \& Vynnychenko, 2017; Lyulyov et al., 2015; Melnyk et al., 2018). At the same time, the development of the financial sector creates favorable conditions for responsible investment in energy development and production restructuring using environmentally friendly technologies (Brychko et al., 2019; Lyeonov \& Liuta, 2016).

The tasks of sustainable development require the interaction of economic agents at the level of the state, regions and individual industries, which will balance the manifestations of economic, environmental and energy security (Spremberg et al., 2017; Raszkowski \& Bartniczak, 2018; Razminiene, 2019; Petrushenko et al., 2020; Kolosok et al., 2018). This approach requires finding tools that will ensure the optimal growth of various manifestations of national security, while maximizing its overall level and avoiding imbalances in its components. In addition, the development of tools for national security should take into account all possible structural changes in the national economy, which will achieve certain goals of the introduction of new instruments (Vasilyeva et al., 2019). The effectiveness of environmental, energy and economic security can be achieved through the use of a set of regulatory measures, especially financial and economic measures (Skare \& Porada-Rochoń, 2019; Lyulyov et al., 2021a; Kouassi, 2018). And the most effective of them is the system of environmental taxation. That is, one of the most important methods is environmental taxes, which allow to implement the necessary regulation with minimal economic costs. The use of environmental taxes allows to perform environmental and compensatory functions. That is, on the one hand, it provides incentives for entities to rationally use and store resources, 
and on the other hand, to cover existing and possible losses from their unfair use or abuse. World experience demonstrates successful implementation of environmental taxes to achieve certain goals of national environmental policy (Miller, 2019).

The analysis of the existing literary achievements proves that the aspect of studying the field of ecology, and especially ecological taxation in terms of ensuring the security of the state, is still not sufficiently studied. This, in turn, does not allow to organize, formalize and sufficiently realize the existing financial potential of the environmental sector, as well as to ensure a sophisticated system of national security, which it directly affects. Synchronization of the goals of national policies of sustainable development and national security has led to an increase in the role of environmental taxes and the emergence of significant convergent trends in their dynamics (Vysochyna et al., 2020a). On the other hand, the process of transformation of tax policies of countries in the context of finding the most favorable operating conditions for national and international economic agents is incomplete (Boiko \& Samusevych, 2017). This proves the importance of finding the optimal structure of the tax system that can maximize the effectiveness of tax policy. Accordingly, in the context of this study, the modeling of such a structure of environmental taxes, which maximizes the total effect of growth of the three components of national security (economic, environmental and energy).

\section{METHODOLOGY}

The methodology of building a multi-parameter model for optimizing the structure of environmental taxes in the context of national security involves the implementation of the following sequence of stages:

1 stage. Collection and processing of input statistical information in terms of optimizing the structure of environmental taxes in the context of national security. Substantiation of the indicators to be used to assess the components of national security (environmental, energy and economic security) was carried out in the works (Samusevych et al., 2021). The parameters of measurement national security were selected by testing their sensitivity to the impact of environmental taxes (using Granger Causality test).

Thus, environmental security indicators include: $\mathrm{CO} 2$ emissions, metric tons per capita; methane emissions, \% change from 1990; nitrous oxide emissions, \% change from 1990; fertilizer consumption, kilograms per hectare of arable land; total fisheries production growth, annual \%; total greenhouse gas emissions, \% change from 1990. Selected energy security indicators include: CO2 emissions from electricity and heat production, \% of fuel combustion; CO2 intensity, $\mathrm{kg}$ per $\mathrm{kg}$ of oil equivalent energy use; electricity production from oil, gas and coal sources, $\%$ of total; energy imports, net $\%$ of energy use; combustible renewables and waste, \% of total energy; energy use ( $\mathrm{kg}$ of oil equivalent) per \$1,000 GDP, constant 2011 PPP; fossil fuel energy consumption, \% of total. Group of economic security indicators consists on: GDP growth, annual \%; income share held by lowest 20\%; industry (including construction) value added, annual $\%$ growth; current account balance, $\%$ of GDP.

The study included six countries (Belgium, Denmark, France, Austria, Finland and the United Kingdom) and covers 1994-2019. Analysis of the tax systems of each country allowed to select from two to nine environmental taxes that have the potential to simultaneously affect all three components of national security.

At this stage, in terms of interpolation of input statistics, gaps were processed using the method of average growth rate, in terms of extrapolation - forecasting the levels of time series by one of the methods of exponential smoothing by the Holt method:

$$
\hat{y}_{t}(\tau)=a_{1, t}+a_{2, t} \cdot \tau
$$




$$
\begin{gathered}
a_{1, t}=a_{1, t-1}+a_{2, t-1}+\alpha_{1} \cdot e_{t}, \\
a_{2, t}=a_{2, t-1}+\alpha_{2} \cdot e_{t}
\end{gathered}
$$

where $\hat{y}_{t}(\tau)$ - the predicted value of the level of the series for the time interval $\tau$, defined for $\mathrm{t}$ first levels;

$a_{1, t}, a_{2, t}$ - initial parameters of the Holt model, calculated by the method of least squares on the basis of data of the first few levels of the studied time series;

$\alpha_{1}, \alpha_{2}$ - smoothing parameters (take possible values within [0;1]), are calculated by applying the method of multidimensional numerical optimization;

$e_{t}$ - remnants of the model.

Stage 2. Construction of integrated assessments of environmental, energy and economic safety based on the use of additive-multiplicative convolution by the Kolmogorov-Gabor method. This method is based on:

2.1 Normalization of input indicators by the method of natural normalization for indicatorsstimulators and Savage normalization for indicators-disincentives;

2.2 Taking into account the priority of component indicators in the formation of integrated assessments of environmental, energy and economic security based on the application of the method of analysis of hierarchies.

2.3 Carrying out nonlinear additive-multiplicative convolution of Kolmogorov-Gabor as integral indicators. This form of convolution allows to take into account the synergetic effect of interdependence of input indicators at their simultaneous influence as set. Additive-multiplicative convolution of Kolmogorov-Gabor takes the following form:

$$
\begin{aligned}
E C K G_{i t}=\sum_{j} v_{j} & \cdot \tilde{n}_{i j t}+\sum_{j} \sum_{j+1} \prod_{j}^{j+1} v_{j} \cdot \tilde{n}_{i j t}+\sum_{j} \sum_{j+1} \sum_{j+2} \prod_{j}^{j+2} v_{j} \cdot \tilde{n}_{i j t} \\
& +\sum_{j} \sum_{j+1} \sum_{j+2} \sum_{j+3} \prod_{j}^{j+3} v_{j} \cdot \tilde{n}_{i j t} \\
& +\sum_{j} \sum_{j+1} \sum_{j+2} \sum_{j+3} \sum_{j+4} \prod_{j}^{j+4} v_{j} \cdot \tilde{n}_{i j t}+\sum_{j} \sum_{j+1} \sum_{j+2} \sum_{j+3} \sum_{j+4} \sum_{j+5} \prod_{j}^{j+5} v_{j} \cdot \tilde{n}_{i j t}
\end{aligned}
$$

where $E C K G_{i t}$ - Kolmogorov-Gabor integrated indicator of the ecological component of national security in terms of the i-th country for the t-th year;

$v_{j}$-weighting factor of the $\mathrm{j}$-th indicator;

$\tilde{n}_{i j t}$ - normalized value of the $j$-th indicator in terms of the $\mathrm{i}$-th country for the $\mathrm{t}$-th year. 


$$
\begin{aligned}
E N K G_{i t}=\sum_{j} v_{j} \cdot \tilde{n}_{i j t}+\sum_{j} \sum_{j+1} \prod_{j}^{j+1} v_{j} \cdot \tilde{n}_{i j t}+\sum_{j} \sum_{j+1} \sum_{j+2} \prod_{j}^{j+2} v_{j} \cdot \tilde{n}_{i j t} \\
+\sum_{j} \sum_{j+1} \sum_{j+2} \sum_{j+3} \prod_{j}^{j+3} v_{j} \cdot \tilde{n}_{i j t} \\
+\sum_{j} \sum_{j+1} \sum_{j+2} \sum_{j+3} \sum_{j+4} \prod_{j}^{j+4} v_{j} \cdot \tilde{n}_{i j t} \\
+\sum_{j} \sum_{j+1} \sum_{j+2} \sum_{j+3} \sum_{j+4} \sum_{j+5} \prod_{j}^{j+5} v_{j} \cdot \tilde{n}_{i j t}+\sum_{j} \sum_{j+1} \sum_{j+2} \sum_{j+3} \sum_{j+4} \sum_{j+5} \prod_{j}^{j+5} v_{j} \cdot \tilde{n}_{i j t} \\
+\sum_{j} \sum_{j+1} \sum_{j+2} \sum_{j+3} \sum_{j+4} \sum_{j+5} \sum_{j+6} \prod_{j} v_{j} \cdot \tilde{n}_{i j t}
\end{aligned}
$$

where $E N K G_{i t}-$ Kolmogorov - Gabor energy integral index component of national security in terms of the i-th country for the $t$-th year;

$$
\begin{aligned}
\operatorname{ECONKG}_{i t}= & \sum_{j} v_{j} \cdot \tilde{n}_{i j t}+\sum_{j} \sum_{j+1} \prod_{j}^{j+1} v_{j} \cdot \tilde{n}_{i j t}+\sum_{j} \sum_{j+1} \sum_{j+2} \prod_{j}^{j+2} v_{j} \cdot \tilde{n}_{i j t} \\
& +\sum_{j} \sum_{j+1} \sum_{j+2} \sum_{j+3} \prod_{j}^{j+3} v_{j} \cdot \tilde{n}_{i j t}
\end{aligned}
$$

where $E$ CONKG $i t-$ Kolmogorov - Gabor integral index of economic component of national security in terms of the $\mathrm{i}$-th country for the $\mathrm{t}$-th year

Stage 3. Construction of the generalizing characteristic of the level of national security on the basis of application of additive-multiplicative convolution by the Kolmogorov - Gabor method:

$$
\begin{gathered}
N B K G_{i t}=E N K G_{i t}+E C K G_{i t}+E \operatorname{CONKG} G_{i t}+E N K G_{i t} \cdot E C K G_{i t}+E N K G_{i t} \cdot E \operatorname{CONKG} G_{i t} \\
+E C K G_{i t} \cdot E \operatorname{CONKG} G_{i t}+E N K G_{i t} \cdot E C K G_{i t} \cdot E \operatorname{CONKG} G_{i t}
\end{gathered}
$$

where $N B K G_{i t}$ - the level of national security of the country for the $\mathrm{t}$-th year.

Stage 4. Construction of multiple linear and nonlinear ridge regression equations of dependence of the level of national security of six countries (Belgium, Denmark, France, Austria, Finland, Great Britain) on independent variables - shares of environmental tax revenues by types of total environmental taxes:

$$
N B K G_{B t}=b_{0}+b_{1} \cdot x_{1}+b_{2} \cdot x_{2}+b_{3} \cdot x_{1} \cdot x_{2}
$$

Ae $N B K G_{B t}$ - the level of national security of Kolmogorov-Gabor for Belgium;

$x_{1}$ - the share of environmental charge in the total amount of environmental taxes;

$x_{2}$ - APETRA contribution share in the total amount of environmental taxes. 
Models of national security dependence from environmental taxation structure for the others 5 countries are presented in Annex A.

Stage 5. Formalization of the optimization model of the structure of environmental taxes, which maximizes the level of national security through the application of the simplex method and the method of the general reduced gradient.

$$
\begin{gathered}
N B K G_{i t}=f\left(x_{1}, \ldots x_{k}, \ldots, x_{n}\right) \rightarrow \max \\
\left\{\begin{array}{c}
x_{1}, \ldots x_{k}, \ldots, x_{n} \geq 0 \\
\min _{k=1 \div n} x_{k}+\sigma_{k} \leq x_{k} \leq \max _{k=1 \div n} x_{k}+\sigma_{k}
\end{array}\right.
\end{gathered}
$$

where $\quad N B K G_{i t}$ - the level of national security of the i-th country for the $\mathrm{t}$-th year;

$x_{k}-\mathrm{k}$-th variable, which takes values from 1 to $\mathrm{n}$, and characterizes the share of the k-th type of tax in the total amount of environmental taxes;

$\min _{k=1 \div n} x_{k}$ - the minimum possible value of the share of the $\mathrm{k}$-th type of tax in the total amount of environmental taxes for the study period;

$\max _{k=1 \div n} x_{k}$ - the maximum possible value of the share of the $\mathrm{k}$-th type of tax in the total amount of environmental taxes for the study period;

$\sigma_{k}$ - the standard deviation of the share of the k-th type of tax in the total amount of environmental taxes for the study period.

Stage 6. Spectral analysis of environmental, energy and economic security assessment for the optimal level of national security.

- for Belgium:

$$
\left\{\begin{array}{c}
E N K G_{i t}=e_{0}+e_{1} \cdot N B K G_{i t} \\
E C K G_{i t}=c_{0}+c_{1} \cdot N B K G_{i t} \\
E \operatorname{CONK} G_{i t}=d_{0}+d_{1} \cdot N B K G_{i t}
\end{array}\right.
$$

- for Denmark, France and Austria

$$
\left\{\begin{array}{c}
E N K G_{i t}=e_{0}+e_{1} \cdot N B K G_{i t} \\
E C K G_{i t}=c_{0}+c_{1} \cdot N B K G_{i t} \\
E C O N K G_{i t}=d_{0}+d_{1} \cdot N B K G_{i t}^{2}+d_{2} \cdot N B K G_{i t}{ }^{3}+ \\
+d_{3} \cdot N B K G_{i t}{ }^{\frac{1}{2}}+d_{4} \cdot \ln \left(N B K G_{i t}\right)+d_{4} \cdot \log \left(N B K G_{i t}\right)+\frac{d_{4}}{N B K G_{i t}}
\end{array}\right.
$$

- for Finland: 


$$
\left\{\begin{array}{c}
E N K G_{i t}=e_{0}+e_{1} \cdot N B K G_{i t} \\
E C K G_{i t}=c_{0}+c_{1} \cdot N B K G_{i t} \\
E \operatorname{CONK} G_{i t}=d_{0}+d_{1} \cdot N B K G_{i t}{ }^{2}+d_{2} \cdot N B K G_{i t}{ }^{3}+ \\
+d_{3} \cdot N B K G_{i t} t^{\frac{1}{2}}+d_{4} \cdot \ln \left(N B K G_{i t}\right)+d_{4} \cdot \log \left(N B K G_{i t}\right)+\frac{d_{4}}{N B K G_{i t}}
\end{array}\right.
$$

- for the United Kingdom:

$$
\left\{\begin{array}{c}
E N K G_{i t}=e_{0}+e_{1} \cdot N B K G_{i t} \\
E C K G_{i t}=c_{0}+c_{1} \cdot N B K G_{i t} \\
E C O N K G_{i t}=d_{0}+d_{1} \cdot N B K G_{i t}{ }^{2}+d_{2} \cdot N B K G_{i t}{ }^{3}+ \\
+d_{3} \cdot N B K G_{i t}{ }^{\frac{1}{2}}+d_{4} \cdot \ln \left(N B K G_{i t}\right)+d_{4} \cdot \log \left(N B K G_{i t}\right)+\frac{d_{4}}{N B K G_{i t}}
\end{array}\right.
$$

\section{EMPIRICAL RESULTS AND DISCUSSION}

The construction of multiple linear and nonlinear ridge regression equations of dependence of the national security level of six countries on independent variables - shares of environmental tax revenues by type of the total amount of environmental taxes allowed to obtain results to assess the quantitative impact of individual environmental taxes and their combinations on national security. The evaluation was performed using the tools Statistica, Statistics / Multiple Regression for the case of linear models and Statistics / Advanced Linear / Nonlinear Models / Fixed Nonlinear Regression for the case of nonlinear models taking into account the Ridge Regression mark. The evaluation results obtained for Belgium are shown in Table 1.

Table 1

The results of statistical analysis of the dependence of the integrated national security index KolmogorovGabor on the share of revenues from environmental taxes by type of the total amount of environmental taxes for Belgium for the period 1994-2019

\begin{tabular}{|c|c|c|c|c|c|c|}
\hline Variable & Coefficient & Standard Error & $\mathbf{t}$-stat & $\mathbf{P}>|\mathbf{t}|$ & \multicolumn{2}{|c|}{$\mathbf{9 5 \%}$ Confidence Interval } \\
\hline Y-intercept & 0,523 & 0,025 & 20,4213 & $8,61 \mathrm{E}-16$ & 0,470 & 0,576 \\
\hline $\mathrm{x} 1$ & 29,657 & 125,190 & 0,236 & 0,814 & $-229,972$ & 289,286 \\
\hline $\mathrm{x} 2$ & 7,938 & 2,630 & 3,017 & 0,006 & 2,482 & 13,394 \\
\hline $\mathrm{x} 1 \mathrm{x} 2$ & $-807,159$ & 4905,539 & $-0,164$ & 0,870 & $-10980,6$ & 9366,306 \\
\hline
\end{tabular}

Source: own calculation

The results presented in the table allow us to assess the separate impact of each of the studied environmental taxes on national security while operating in the country's environmental tax system, and take into account the synergistic effects arising from the interaction of their impact on the integrated level of national security. 
Based on the data in Table 1 for the example of Belgium, the objective function of the problem of optimizing the structure of environmental taxes in the context of national security is as follows:

$$
N B K G_{B t}=0,523+29,657 \cdot x_{1}+7,938 \cdot x_{2}-807,159 \cdot x_{1} \cdot x_{2}
$$

ae $N B K G_{B t}$ - the level of national security of Kolmogorov-Gabor for Belgium;

$x_{1}$ - the share of environmental charge in the total amount of environmental taxes;

$x_{2}$ - APETRA contribution share in the total amount of environmental taxes.

Generalizing models corresponding to equation (17) to describe the multiplex effect of combinations of environmental taxes on national security for other countries presented in Annex B. It should be noted that in systems with the simultaneous operation of more than two taxes, the impact of individual combinations of certain taxes, which are effective in assessing their separate impact, was also assessed. This allows maximizing their positive multiplex effects on the growth of national security and avoiding negative synergies through the simultaneous introduction of taxes, the combination of which poses a threat to national security.

Formalization of the optimization model of the structure of environmental taxes, which ensures the maximization of the level of national security was carried out using the simplex method (France, Finland) and the method of the general reduced gradient (Belgium, Denmark, Austria, Great Britain). For the example of Belgium, we will build an economic-mathematical multi-parameter model for optimizing the structure of environmental taxes in the context of national security:

$$
\begin{gathered}
N B K G_{B t}=0,523+29,657 \cdot x_{1}+7,938 \cdot x_{2}-807,159 \cdot x_{1} \cdot x_{2} \rightarrow \max \\
\left\{\begin{array}{c}
x_{1}, x_{2} \geq 0 \\
0,001024 \leq x_{1} \leq 0,003588 \\
0,013219 \leq x_{1} \leq 0,050655
\end{array}\right.
\end{gathered}
$$

Solving the optimization task (23) using the method of the general reduced gradient allowed to obtain the following results (table 2).

Table 2

\begin{tabular}{|c|c|c|c|}
\hline \multirow[t]{2}{*}{ Indicator } & \multicolumn{2}{|c|}{$\begin{array}{c}\text { Parameters of structural ratios of selected } \\
\text { parameters of ecological taxes }\end{array}$} & \multirow{2}{*}{$\begin{array}{c}\text { Target function of the integrated } \\
\text { level of national security }\end{array}$} \\
\hline & $\mathrm{x} 1$ & $\mathrm{x} 2$ & \\
\hline Optimal value & 0,0134 & 0,0036 & 0,9057 \\
\hline Minimum value & 0,0000 & 0,0000 & 0,3587 \\
\hline Maximum value & 0,0024 & 0,0376 & 0,8586 \\
\hline $\begin{array}{l}\text { Minimum value, corrected by } \\
\text { standard deviation }\end{array}$ & 0,0012 & 0,0138 & 0,4997 \\
\hline $\begin{array}{l}\text { Maximum value, corrected by } \\
\text { standard deviation }\end{array}$ & 0,0034 & 0,0508 & 1,0000 \\
\hline
\end{tabular}

The results of optimizing the structure of environmental taxes in the context of national security in

$$
\text { Belgium }
$$

Source: own calculation

Therefore, it is determined that the structural optimization of the environmental tax system in Belgium should provide for a reduction in the level of APETRA contribution while increasing revenues 
from environmental charge in the overall structure of environmental taxes. At the same time, a study conducted for Denmark (Table 3) showed that the structure of environmental taxes formed in the country is close to optimal in the context of national security. Thus, the obtained ratios provide only minor adjustments to maximize the multiplex effect of the estimated environmental taxes.

Table 3

The results of optimizing the structure of environmental taxes in the context of national security in

Denmark

\begin{tabular}{|c|c|c|c|c|c|c|}
\hline \multirow[t]{2}{*}{ Indicator } & \multicolumn{5}{|c|}{$\begin{array}{l}\text { Parameters of structural ratios of selected parameters of } \\
\text { ecological taxes }\end{array}$} & \multirow{2}{*}{$\begin{array}{l}\text { Target function of } \\
\text { the integrated level } \\
\text { of national security }\end{array}$} \\
\hline & $\mathrm{x} 1$ & $\mathrm{x} 2$ & $\mathrm{x} 3$ & $\mathrm{x} 4$ & $\mathrm{x} 5$ & \\
\hline Optimal value & 0,0202 & 0,1731 & 0,0036 & 0,0009 & 0,0083 & 0,6988 \\
\hline Minimum value & 0,0131 & 0,0988 & 0,0003 & 0,0000 & 0,0070 & 0,2471 \\
\hline Maximum value & 0,0380 & 0,1542 & 0,0083 & 0,0008 & 0,0109 & 0,8368 \\
\hline $\begin{array}{l}\text { Minimum value, corrected by } \\
\text { standard deviation }\end{array}$ & 0,0202 & 0,1178 & 0,0021 & 0,0002 & 0,0082 & 0,4102 \\
\hline $\begin{array}{l}\text { Maximum value, corrected by } \\
\text { standard deviation }\end{array}$ & 0,0451 & 0,1731 & 0,0102 & 0,0010 & 0,0121 & 1,0000 \\
\hline
\end{tabular}

Source: own calculation

The next country for evaluation was France (Table 4). The results show that in order to optimize the multiplexed impact of environmental taxes on national security at the same time in terms of its environmental, economic and energy components, it is advisable to make significant structural adjustments to their levels.

Table 4

The results of optimizing the structure of environmental taxes in the context of ensuring the national security of France

\begin{tabular}{|l|c|c|c|c|c|c|c|c|}
\hline \multirow{2}{*}{\begin{tabular}{|l|c|c|c|c|c|c|} 
Indicator \\
\cline { 2 - 9 }
\end{tabular}} & \multicolumn{2}{|c|}{ Parameters of structural ratios of selected parameters of ecological taxes } & $\begin{array}{c}\text { Target function } \\
\text { of the } \\
\text { integrated level } \\
\text { of national } \\
\text { security }\end{array}$ \\
\hline Optimal value & 0,0031 & 0,2221 & 0,0346 & 0,0346 & 0,0000 & 0,0002 & 0,0061 & 0,9962 \\
\hline Minimum value & 0,0000 & 0,0000 & 0,0342 & 0,0036 & 0,0002 & 0,0099 & 0,0032 & 0,2489 \\
\hline Maximum value & 0,0079 & 0,1654 & 0,0446 & 0,0153 & 0,0024 & 0,0132 & 0,0054 & 0,8265 \\
\hline $\begin{array}{l}\text { Minimum value, } \\
\text { corrected by standard } \\
\text { deviation }\end{array}$ & 0,0031 & 0,0567 & 0,0378 & 0,0073 & 0,0008 & 0,0108 & 0,0038 & 0,4224 \\
\hline $\begin{array}{l}\text { Maximum value, } \\
\text { corrected by standard } \\
\text { deviation }\end{array}$ & 0,0110 & 0,2221 & 0,0483 & 0,0190 & 0,0031 & 0,0142 & 0,0061 & 1,0000 \\
\hline
\end{tabular}

Source: own calculation

It should be noted that the existing approaches to the collection of environmental taxes in Austria need significant adjustments in terms of maximizing their regulatory capacity to ensure national security 
(Table 5). In particular, the role of recurrent car taxes should be significantly increased in order to achieve the optimal effect. At the same time, the rest of the taxes should be left in a balanced proportion.

Table 5

The results of optimizing the structure of environmental taxes in the context of ensuring the national security of Austria

\begin{tabular}{|l|c|c|c|c|c|c|}
\hline \multirow{2}{*}{ Indicator } & \multicolumn{5}{|c|}{$\begin{array}{c}\text { Parameters of structural ratios of selected } \\
\text { parameters of ecological taxes }\end{array}$} & $\begin{array}{c}\text { Target function of the integrated } \\
\text { level of national security }\end{array}$ \\
\cline { 2 - 6 } & $\mathrm{x} 1$ & $\mathrm{x} 2$ & $\mathrm{x} 3$ & $\mathrm{x} 4$ & $\mathrm{x} 5$ & 0,9807 \\
\hline Optimal value & 0,0566 & 0,6074 & 0,0056 & 0,0746 & 0,0815 & 0,3359 \\
\hline Minimum value & 0,0400 & 0,1020 & 0,3608 & 0,0000 & 0,0814 & 0,8571 \\
\hline Maximum value & 0,1060 & 0,5243 & 0,9223 & 0,3007 & 0,3737 & 0,4788 \\
\hline $\begin{array}{l}\text { Minimum value, corrected } \\
\text { by standard deviation }\end{array}$ & 0,0566 & 0,1851 & 0,4746 & 0,0722 & 0,1389 & 0 \\
\hline
\end{tabular}

Source: own calculation

The results obtained for Finland (Table 6) also indicate that the predominance excise duty in the general structure will be optimal.

Table 6

The results of optimizing the structure of environmental taxes in the context of ensuring the national security of Finland

\begin{tabular}{|c|c|c|c|c|c|c|c|c|c|c|}
\hline \multirow[t]{2}{*}{ Indicator } & \multicolumn{9}{|c|}{$\begin{array}{c}\text { Parameters of structural ratios of selected } \\
\text { parameters of ecological taxes }\end{array}$} & \multirow{2}{*}{$\begin{array}{c}\text { Target function of the } \\
\text { integrated level of national } \\
\text { security }\end{array}$} \\
\hline & $\mathrm{x} 1$ & $\mathrm{x} 2$ & $\mathrm{x} 3$ & $\mathrm{x} 4$ & $\mathrm{x} 5$ & $\mathrm{x} 6$ & $\mathrm{x} 7$ & $\mathrm{x} 8$ & $\mathrm{x} 9$ & \\
\hline Optimal value & 0,0005 & 0,6600 & 0,0065 & 0,0020 & 0,0038 & 0,1100 & 0,0400 & 0,0069 & 0,0586 & 0,9794 \\
\hline Minimum value & 0,0000 & 0,4739 & 0,0000 & 0,0010 & 0,0027 & 70,0772 & 0,0187 & 0,0035 & 0,0538 & 0,2982 \\
\hline Maximum value & 0,0027 & 0,6658 & 0,0018 & 0,0040 & 0,0063 & 0,1807 & 0,0382 & 0,0148 & 0,0883 & 0,8491 \\
\hline $\begin{array}{l}\text { Minimum value, corrected } \\
\text { by standard deviation }\end{array}$ & 0,0006 & 0,5378 & 0,0006 & 0,0020 & 0,0038 & 0,1113 & 0,0248 & 0,0069 & 0,0661 & 0,4490 \\
\hline
\end{tabular}

Source: own calculation

At the same time, the system of environmental taxes formed in the United Kingdom can be considered close to optimal (Table 7).

Table 7

The results of optimizing the structure of environmental taxes in the context of national security in the United Kingdom

\begin{tabular}{|c|c|c|c|c|c|}
\hline \multirow[t]{2}{*}{ Indicator } & \multicolumn{4}{|c|}{$\begin{array}{l}\text { Parameters of structural ratios of selected parameters of } \\
\text { ecological taxes }\end{array}$} & \multirow{2}{*}{$\begin{array}{l}\text { Target function of } \\
\text { the integrated level } \\
\text { of national security }\end{array}$} \\
\hline & $\mathrm{x} 1$ & $\mathrm{x} 2$ & $\mathrm{x} 3$ & $\mathrm{x} 4$ & \\
\hline Optimal value & 0,0241 & 0,0020 & 0,0250 & 0,1800 & 0,9862 \\
\hline Minimum value & 0,0018 & 0,0000 & 0,0000 & 0,0000 & 0,3972 \\
\hline Maximum value & 0,0742 & 0,0014 & 0,0283 & 0,1250 & 0,8615 \\
\hline $\begin{array}{l}\text { Minimum value, corrected by } \\
\text { standard deviation }\end{array}$ & 0,0241 & 0,0006 & 0,0079 & 0,0412 & 0,5357 \\
\hline Optimal value & 0,0965 & 0,0020 & 0,0361 & 0,1662 & 1,0000 \\
\hline
\end{tabular}

Source: own calculation 
Spectral analysis of the assessment of environmental, energy and economic security for the optimal level of national security revealed the following interdependencies between the components of national security.

- for Belgium:

$$
\left\{\begin{array}{l}
E N K G_{i t}=-0,431+1,343 \cdot N B K G_{i t} \\
E C K G_{i t}=-0,225+1,078 \cdot N B K G_{i t} \\
E \operatorname{CONKG} G_{i t}=0,956-0,988 \cdot N B K G_{i t}
\end{array}\right.
$$

- for Denmark:

$$
\left\{\begin{array}{c}
E N K G_{i t}=-0,135+1,056 \cdot N B K G_{i t} \\
E C K G_{i t}=0,231+0,963 \cdot N B K G_{i t} \\
E \operatorname{CONKG_{it}=} 0,405+0,020 \cdot N B K G_{i t}^{2}+0,000043 \cdot N B K G_{i t}{ }^{3}- \\
-0,031 \cdot N B K G_{i t}^{\frac{1}{2}}-0,033 \cdot \ln \left(N B K G_{i t}\right)-0,076 \cdot \log \left(N B K G_{i t}\right)+\frac{0,044}{N B K G_{i t}}
\end{array}\right.
$$

- for France:

$$
\left\{\begin{array}{c}
E N K G_{i t}=-0,142+1,050 \cdot N B K G_{i t} \\
E C K G_{i t}=-0,165+1,195 \cdot N B K G_{i t} \\
E \operatorname{CONKG_{it}}=0,604-0,210 \cdot N B K G_{i t}{ }^{2}-0,161 \cdot N B K G_{i t}{ }^{3}- \\
-0,243 \cdot N B K G_{i t}{ }^{\frac{1}{2}}-0,045 \cdot \ln \left(N B K G_{i t}\right)-0,105 \cdot \log \left(N B K G_{i t}\right)-\frac{0,033}{N B K G_{i t}}
\end{array}\right.
$$

- for Austria:

$$
\left\{\begin{array}{c}
E N K G_{i t}=0,073+0,772 \cdot N B K G_{i t} \\
E C K G_{i t}=-0,236+1,133 \cdot N B K G_{i t} \\
E \operatorname{CONK} G_{i t}=0,582-0,079 \cdot N B K G_{i t}^{2}-0,087 \cdot N B K G_{i t}{ }^{3}- \\
-0,092 \cdot N B K G_{i t}{ }^{\frac{1}{2}}-0,022 \cdot \ln \left(N B K G_{i t}\right)-0,051 \cdot \log \left(N B K G_{i t}\right)-\frac{0,006}{N B K G_{i t}}
\end{array}\right.
$$

-for Finland:

$$
\left\{\begin{array}{c}
E N K G_{i t}=-0,233+1,104 \cdot N B K G_{i t} \\
E C K G_{i t}=-0,146+1,065 \cdot N B K G_{i t} \\
E \operatorname{CONKG_{it}}=0,694-0,243 \cdot N B K G_{i t}{ }^{2}-0,370 \cdot N B K G_{i t}{ }^{3}- \\
-0,124 \cdot N B K G_{i t}{ }^{\frac{1}{2}}-0,007 \cdot \ln \left(N B K G_{i t}\right)-0,016 \cdot \log \left(N B K G_{i t}\right)-\frac{0,032}{N B K G_{i t}}
\end{array}\right.
$$

-for United Kingdom: 


$$
\left\{\begin{array}{c}
E N K G_{i t}=-0,274+1,134 \cdot N B K G_{i t} \\
E C K G_{i t}=0,110+0,824 \cdot N B K G_{i t} \\
E C O N K G_{i t}=0,873-253 \cdot N B K G_{i t}{ }^{2}-0,331 \cdot N B K G_{i t}{ }^{3}- \\
-0,115 \cdot N B K G_{i t}{ }^{\frac{1}{2}}+0,021 \cdot \ln \left(N B K G_{i t}\right)+0,048 \cdot \log \left(N B K G_{i t}\right)-\frac{0,097}{N B K G_{i t}}
\end{array}\right.
$$

\section{CONCLUSION}

The study aims to substantiate and confirm the hypothesis of the formation of the optimal structure of environmental taxes, which maximizes the integrated effect of their impact on national security. Empirical calculations have shown that environmental tax systems in European countries have different levels of their multiplex effectiveness in the context of national security. Construction of optimization models allowed to identify vectors of change in the structure of environmental taxes, which will increase their integrated regulatory efficiency. At the same time, the spectral analysis revealed the transmission effects that occur between the three components of national security - environmental, economic and energy. All this creates a basis for improving national tax policies in terms of achieving the strategic goals of national security, as well as its individual components.

\section{ACKNOWLEDGEMENT}

This work was supported by the Ministry of Education and Science of Ukraine and National Research Foundation of Ukraine and performed the results of the projects «Structural-functional multiplex model of ecological tax system building in Ukraine in the context of national security» (registration number 0119U100759); «Data-Mining for Countering Cyber Fraud and Money Laundering in the Context of Digitalization of the Financial Sector of the Ukrainian Economy» (registration number 0121U100467); «Stochastic modelling of road map for harmonizing national and European standards for energy market regulation in the transition to a circular and carbon-free economy» (0120U104807).

\section{REFERENCES}

Ahmed, U., AlZgool, M. R. H., \& Shah, S. M. M. (2019). The Impact of Green Human Resource Practices on Environmental Sustainability. Polish Journal of Management Studies, 20 (1), 9-18. DOI: 10.17512/pjms.2019.20.1.01.

Alimuddin, A., Hasnidar, H., Bura, M. T., \& Anggraeni, F. L. (2020). The Effect of Applying Balanced Scorecards Environmental Performance. Polish Journal of Management Studies, 21 (1), 22-33. DOI: 10.17512/pjms.2020.21.1.02

Amrin, A. K., \& Nurlanova N. K. (2020). Innovation Activity: Localization, New Trends and Assessment Methods Engineering Economics, 31(2), 134-144. DOI: https://doi.org/10.5755/j01.ee.31.2.21501

Antonyuk, N., Plikus, I., \& Jammal, M. (2021). Sustainable business development vision under the covid-19 pandemic. Health Economics and Management Review, 2(1), 37-43. https://doi.org/10.21272/hem.2021.1-04

Atkociuniene, Z. O. \& Mikalauskiene, A. (2019). Knowledge Management Influence on Implementing Sustainable Development Means in the Organization. Transformations in Business \& Economics, 18(3), 546-564.

Atta Mills, E. F. E., Zeng, K., \& Baafi, M. A. (2020). The economy-energy-environment Nexus in IMF's Top 2 biggest economies: a TY approach. Journal of Business Economics and Management, 21(1), 1-22. https://doi.org/10.3846/jbem.2019.11321 
Bilan, Y., Tiutiunyk, I., Lyeonov, S., \& Vasylieva, T. (2020). Shadow economy and economic development: A panel cointegration and causality analysis. International Journal of Economic Policy in Emerging Economies, 13(2), 173-193. doi:10.1504/IJEPEE.2020.107929

Boiko, A., \& Samusevych, I. (2017). The role of tax competition between the countries of the world and the features of determining the main tax competitors of Ukraine among the European countries. Financial Markets, Institutions and Risks, 1(1), 72-79. http://doi.org/10.21272/fmir.1(1).72-79.2017.

Brychko, M., Polách, J., Kuzmenko, O., \& Olejarz, T. (2019). Trust cycle of the finance sector and its determinants: The case of Ukraine. Journal of International Studies, 12(4), 300-324. doi:10.14254/2071-8330.2019/12-4/20

Cebula, J., \& Pimonenko, T. (2015). Comparison financing conditions of the development biogas sector in Poland and Ukraine. International Journal of Ecology and Development, 30(2), 20-30. Retrieved from https://www.scopus.com/record/display.uri?eid=2-s2.0-84928012546\&origin=resultslist

Cebula, J., Chygryn, O., Chayen, S. V., \& Pimonenko, T. (2018). Biogas as an alternative energy source in Ukraine and Israel: Current issues and benefits. International Journal of Environmental Technology and Management, 21(5-6), 421-438. doi:10.1504/IJETM.2018.100592

Chovancová, J., \& Tej, J. (2020). Decoupling economic growth from greenhouse gas emissions: the case of the energy sector in V4 countries. Equilibrium. Quarterly Journal of Economics and Economic Policy, 15(2), $235-251$. https://doi.org/10.24136/eq.2020.011

Didenko, I., Paucz-Olszewska, J., Lyeonov, S., Ostrowska-Dankiewicz, A., \& Ciekanowski, Z. (2020a). Social safety and behavioral aspects of populations financial inclusion: A multicountry analysis. Journal of International Studies, 13(2), 347-359. doi:10.14254/2071-8330.2020/13-2/23

Didenko, I., Volik, K., Vasylieva, T., Lyeonov, S., \& Antoniuk, N. (2020b). Migration, environment, and country safety: Analysis of touchpoints. Paper presented at the E3S Web of Conferences, 202 doi:10.1051/e3sconf/202020203028

Didenko, I., Volik, K., Vasylieva, T., Lyeonov, S., \& Antoniuk, N. (2021). Environmental migration and country security: Theoretical analysis and empirical research. Paper presented at the E3S Web of Conferences, 234 doi:10.1051/e3sconf/202123400010

Dkhili, H. (2018). Environmental performance and institutions quality: evidence from developed and developing countries. Marketing and Management of Innovations,(3), 333-344. 10.21272/mmi.2018.3-30

Eddassi, H. (2020). Fiscal Regime and Tax Policy in Resource-Rich Countries In The Process Of Globalization: Literature Review. SocioEconomic Challenges, 4(2), 67-77. https://doi.org/10.21272/sec.4(2).67-77.2020.

Fomina, J., Vynnychenko, N. (2017). Fiscal transparency: cross-country comparisons. Business Ethics and Leadership, 1(2), 39-46. Doi: 10.21272/bel.1(2).39-46.2017

Formankovaa, S., Trenz, O., Faldik, O., Kolomaznik, J., \& Vanek, P. (2018). The future of investing-sustainable and responsible investing. Marketing and Management of Innovations, 2, 94-102. 10.21272/ mmi.2018.2-08

He, S. (2019). The Impact of Trade on Environmental Quality: A Business Ethics Perspective and Evidence from China. Business Ethics and Leadership, 3(4), 43-48. http://doi.org/10.21272/bel.3(4).43-48.2019.

Holotová, M., Nagyová, L., \& Holota, T. (2020). The impact of environmental responsibility on changing consumer behaviour - sustainable market in Slovakia. Economics and Sociology, 13(3), 84-96. doi:10.14254/2071789X.2020/13-3/6

Jonek-Kowalska, I. (2019). Transformation of energy balances with dominant coal consumption in European economies and Turkey in the years 1990-2017. Oeconomia Copernicana, 10(4), 627-647. https://doi.org/10.24136/oc.2019.030

Kolosok, S., Dementov, V., Korol, S., \& Panchenko, O. (2018). Public policy and international investment position in European integration of Ukraine. Journal of Applied Economic Sciences, 13(8), 2375-2384. Retrieved from https://www.scopus.com/record/display.uri?eid=2-s2.0-85063559158\&origin=resultslist

Kolosok, S., Myroshnychenko, I., \& Zakharkina, L. (2020). Open data in electrical energy balancing of Ukraine: Green deal and security aspects. Paper presented at the CEUR Workshop Proceedings, 2732 270-281. Retrieved from https://www.scopus.com/record/display.uri?eid=2-s2.0-85096133769\&origin=resultslist 
Kolosok, S., Myroshnychenko, I., Mishenina, H., \& Yarova, I. (2021). Renewable energy innovation in Europe: Energy efficiency analysis. Paper presented at the E3S Web of Conferences, 234 doi:10.1051/e3sconf/202123400021

Kouassi K.B. (2018). Public Spending and Economic Growth in Developing Countries: a Synthesis. Financial Markets, Institutions and Risks, 2(2), 22-30. DOI: 10.21272/fmir.2(2).22-30.2018

Kubaienko, A. (2018). Activation of the Economic Security of Ukraine in Terms of the European Integration. Montenegrin Journal of Economics, 14 (2), 91-114. DOI: 10.14254/1800-5845/2018.14-2.6.

Lesakova, L. (2019). Small and Medium Enterprises and Eco-Innovations: Empirical Study of Slovak SME $\square \mathrm{s}$. Marketing and Management of Innovations, 3, 89-97. http:// doi.org/10.21272/mmi.2019.3-07

Lyeonov, S., \& Liuta, O. (2016). Actual problems of finance teaching in Ukraine in the post-crisis period. The financial crisis: Implications for research and teaching (pp. 145-152) doi:10.1007/978-3-319-20588-5_07

Lyulyov, O., Chortok, Y., Pimonenko, T., \& Borovik, O. (2015). Ecological and economic evaluation of transport system functioning according to the territory sustainable development. International Journal of Ecology and Development, 30(3), 1-10. Retrieved from https://www.scopus.com/record/display.uri?eid=2-s2.084940377261\&origin=resultslist

Lyulyov, O., Paliienko, M., Prasol, L., Vasylieva, T., Kubatko, O., \& Kubatko, V. (2021a). Determinants of shadow economy in transition countries: Economic and environmental aspects. International Journal of Global Energy Issues, 43(2-3), 166-182. Retrieved from https://www.scopus.com/record/display.uri?eid=2-s2.085106862529 \&origin $=$ resultslist

Lyulyov, O., Pimonenko, T., Kwilinski, A., Dzwigol, H., Dzwigol-Barosz, M., Pavlyk, V., \& Barosz, P. (2021b). The impact of the government policy on the energy efficient gap: The evidence from Ukraine. Energies, 14(2) doi:10.3390/en14020373

Masharsky, A., Azarenkova, G., Oryekhova, K., \& Yavorsky, S. (2018). Anti-crisis financial management on energy enterprises as a precondition of innovative conversion of the energy industry: case of Ukraine. Marketing and Management of Innovations, 3, 345-354. 10.21272/mmi.2018.3-31

Medani P. B. (2019). Sustainable Development: Is This Paradigm The Remedy of All Challenges? Does Its Goals Capture The Essence of Real Development and Sustainability? With Reference to Discourses, Creativeness, Boundaries and Institutional Architecture. SocioEconomic Challenges, 3(4), 97-128. http://doi.org/10.21272/sec.3(4).97-128.2019.

Melnyk, L., Sineviciene, L., Lyulyov, O., Pimonenko, T., \& Dehtyarova, I. (2018). Fiscal decentralization and macroeconomic stability: The experience of Ukraine's economy. Problems and Perspectives in Management, 16(1), 105-114. doi:10.21511/ppm.16(1).2018.10

Mentel, G., Vasilyeva, T., Samusevych, Y., Vysochyna, A., Karbach, R., \& Streimikis, J. (2020). The evaluation of economic, environmental and energy security: Composite approach. International Journal of Global Environmental Issues, 19(1-3), 177-195. Retrieved from https://www.scopus.com/record/display.uri?eid=2-s2.085105783764\&origin=AuthorNamesList\&txGid=1943ed9e963f86aa95c9888121201b0a

Mikhaylova, A., Mikhaylov, A., Savchina, O., \& Plotnikova, A. (2019). Innovation landscape of the Baltic region. Administratie si Management Public, (33), 165-180. DOI: 10.24818/amp/2019.33-10.

Miller, A.D. (2019). Current Mining Taxation Policy Implemented by both Mongolia and Kazakhstan: The Development Comparatives between Ulaanbaatar and Astana. Business Ethics and Leadership, 3(2), 3952. http://doi.org/10.21272/bel.3(2).39-52.2019.

Nikodemska-Wołowik, A. M., Marjański, A., \& Brack, A. (2019). Company Values - A Case Study of the Family Enterprise August Storck KG. Journal of Intercultural Management, 11(1), 5-22. DOI: https://doi.org/10.2478/joim-2019-0001

Pavlyk, V. (2020). Assessment of green investment impact on the energy efficiency gap of the national economy. Financial Markets, Institutions and Risks, 4(1), 117-123. http://doi.org/10.21272/fmir.4(1).117-123.2020.

Petrushenko, Y., Kostyuchenko, N., Smolennikov, D., \& Vorontsova, A. (2017). Impact of the participatory financing of international development projects on social capital of the local communities. Problems and Perspectives in Management, 15(3), 183-192. doi:10.21511/ppm.15(3-1).2017.02 
Petrushenko, Y., Vadym, A., Vorontsova, A., \& Ponomarenko, O. (2020). Sustainable development goals as a tool for strategic planning in communities: A bibliometric analysis of research. Paper presented at the E3S Web of Conferences, 202 doi:10.1051/e3sconf/202020203005

Prokopenko, O., Cebula, J., Chayen, S., \& Pimonenko, T. (2017). Wind energy in Israel, Poland and Ukraine: Features and opportunities. International Journal of Ecology and Development, 32(1), 98-107. Retrieved from https://www.scopus.com/record/display.uri?eid=2-s2.0-85010877198\&origin=resultslist

Raszkowski, A., \& Bartniczak, B. (2018). Towards Sustainable Regional Development: Economy, Society, Environment, Good Governance Based on the Example of Polish Regions. Transformations in Business \& Economics, 17(2), 225-245.

Razminiene, K. (2019). Circular economy in clusters' performance evaluation. Equilibrium. Quarterly Journal of Economics and Economic Policy, 14(3), 537-559. https://doi.org/10.24136/eq.2019.026

Romana, F. A. (2020). The Impact of Senior-Managerial Leadership Culture on Value Creation for Shareholders - A Study of Local and Multinational Companies in Portugal. Journal of Intercultural Management, 12 (2), 134-175. DOI: https://doi.org/10.2478/joim-2020-0041

Samusevych, Y., Vysochyna, A., Vasylieva, T., Lyeonov, S., \& Pokhylko, S. (2021). Environmental, energy and economic security: Assessment and interaction. Paper presented at the E3S Web of Conferences, 234 doi:10.1051/e3sconf/202123400012

Sibanda, M., \& Ndlela, H. (2020). The link between carbon emissions, agricultural output and industrial output: evidence from South Africa. Journal of Business Economics and Management, 21(2), 301-316. https://doi.org/10.3846/jbem.2020.11408

Skare, M., \& Porada-Rochoń, M. (2019). Financial and economic development link in transitional economies: a spectral Granger causality analysis 1991-2017. Oeconomia Copernicana, 10(1), 7-35. https://doi.org/10.24136/oc.2019.001

Spremberg, E., Tykhenko, V., Lopa, L. (2017). Public-Private Partnership in the Implementation of National Environmental Projects. SocioEconomic Challenges, 1(4), 73-81. DOI: 10.21272sec.1(4).73-81.2017

Starchenko, L., Lyeonov, S., Vasylieva, T., Pimonenko, T., \& Lyulyov, O. (2021). Environmental management and green brand for sustainable entrepreneurship. Paper presented at the E3S Web of Conferences, 234 doi:10.1051/e3sconf/202123400015

Tiutiunyk, I., Humenna, Yu., \& Flaumer, A. (2021). Covid-19 impact on business sector activity in the EU countries: digital issues. Health Economics and Management Review, 2(1), 54-66. https://doi.org/10.21272/hem.2021.1-06

Us, Ya., Pimonenko, T., Tambovceva, T., \& Segers, J-P. (2020). Green transformations in the healthcare system: the covid-19 impact. Health Economics and Management Review, 1(1), 48-59. https://doi.org/10.21272/hem.2020.104

Vafaei, S.A., Azmoon, I., \& Fekete-Farkas, M. (2019). The Impact of Perceived Sustainable Marketing Policies on Green Customer Satisfaction. Polish Journal of Management Studies, 19 (1), 475-491. DOI: 10.17512/pjms.2019.19.1.36

Vasilyeva, T., Bilan, S., Bagmet, K., \& Seliga, R. (2020a). Institutional development gap in the social sector: Crosscountry analysis. Economics and Sociology, 13(1), 271-294. doi:10.14254/2071-789X.2020/13-1/17

Vasilyeva, T., Kuzmenko, O., Bozhenko, V., \& Kolotilina, O. (2019). Assessment of the dynamics of bifurcation transformations in the economy. Paper presented at the CEUR Workshop Proceedings, 2422 134-146. Retrieved from https://www.scopus.com/record/display.uri?eid=2-s2.0-85071124329\&origin=resultslist

Vasylieva, T. A., Lieonov, S. V., Makarenko, I. O., \& Sirkovska, N. (2017). Sustainability information disclosure as an instrument of marketing communication with stakeholders: markets, social and economic aspects. Marketing and Management of Innovations, 4, 350-357. 10.21272/mmi.2017.4-31

Vasylieva, T., Pavlyk, V., Bilan, Y., Mentel, G., \& Rabe, M. (2021). Assessment of energy efficiency gaps: The case for Ukraine. Energies, 14(5) doi:10.3390/en14051323

Vysochyna, A., Samusevych, Y., \& Starchenko, L. (2020a). Convergence trends of environmental taxation in European countries. Paperpresented at the E3S Web of Conferences, 202 doi:10.1051/e3sconf/202020203031

Vysochyna, A., Stoyanets, N., Mentel, G., \& Olejarz, T. (2020b). Environmental determinants of a country's food security in short-term and long-term perspectives. Sustainability (Switzerland), 12(10) doi:10.3390/su12104090 


\section{ANNEXES}

\section{Annex A}

$$
\begin{aligned}
N B K G_{D t}=f_{0} & +\sum_{i=1}^{5} b_{i} \cdot x_{i}+x_{1} \cdot \sum_{i=2}^{5} b_{i+4} \cdot x_{i}+x_{2} \cdot \sum_{i=3}^{5} b_{i+7} \cdot x_{i}+x_{3} \cdot \sum_{i=4}^{5} b_{i+9} \cdot x_{i} \\
& +b_{15} \cdot \prod_{i=4}^{5} x_{i}+b_{16} \cdot \prod_{i=1}^{3} x_{i}+\prod_{i=1,4} x_{i} \cdot \sum_{i=3,4} b_{i+14} \cdot x_{i}+b_{19} \cdot x_{2} \cdot \prod_{i=2}^{4} x_{i} \\
& +\prod_{i=4,5} x_{i} \cdot \sum_{i=2}^{3} b_{i+18} \cdot x_{i}+b_{22} \cdot \prod_{i=1}^{4} x_{i}+\prod_{i=3}^{5} x_{i} \cdot \sum_{i=1}^{2} b_{i+22} \cdot x_{i}
\end{aligned}
$$

where $\quad N B K G_{D t}$ - the level of national security of Kolmogorov-Gabor for Denmark;

$x_{1}$ - the share of the duty on coal in the total amount of environmental taxes;

$x_{2}$ - the share of the duty on electricity in the total amount of environmental taxes;

$x_{3}$ - the share of pesticide duties in the total amount of environmental taxes;

$x_{4}$ - the share of the duty on tires in the total amount of environmental taxes;

$x_{5}$ - the share of sale of vehicle number plates in the total amount of environmental taxes.

$$
\begin{aligned}
N B K G_{F r t}=b_{0} & +b_{1} \cdot x_{1} \cdot x_{2}+b_{2} \cdot x_{2} \cdot x_{4}+b_{3} \cdot x_{1} \cdot x_{2} \cdot x_{3}+b_{4} \cdot x_{1} \cdot x_{5} \cdot x_{6} \cdot x_{7}+b_{5} \cdot x_{2} \\
& +b_{6} \cdot x_{5} \cdot x_{4}+b_{7} \cdot x_{2} \cdot x_{3}+b_{8} \cdot x_{6} \cdot x_{3}
\end{aligned}
$$

where $\quad N B K G_{F r t}$ - the level of national security of Kolmogorov-Gabor for France;

$x_{1}$ - the share of the CO2-related malus system for vehicle registration in the total amount of environmental taxes;

$x_{2}$ - the share of the contribution to electricity generators for public services they provide in the total amount of environmental taxes;

$x_{3^{-}}$the share of the internal tax on final consumption of electricity in the total amount of environmental taxes;

$x_{4}$ - the share of the internal tax on natural gas in the total amount of environmental taxes;

$x_{5}$ - the share of production taxes in the total amount of environmental taxes;

$x_{6}$ - the share of special fuel tax in foreign communities in the total amount of environmental taxes;

$x_{7}$ - the share of the tax on electricity pylons in the total amount of environmental taxes.

$$
\begin{aligned}
N B K G_{A t}=f_{0} & +\sum_{i=1}^{5} b_{i} \cdot x_{i}+x_{1} \cdot \sum_{i=2}^{5} b_{i+4} \cdot x_{i}+x_{2} \cdot \sum_{i=3}^{5} b_{i+7} \cdot x_{i}+x_{3} \cdot \sum_{i=4}^{5} b_{i+9} \cdot x_{i} \\
& +b_{15} \cdot \prod_{i=4}^{5} x_{i}+b_{16} \cdot \prod_{i=1}^{3} x_{i}+\prod_{i=1,4} x_{i} \cdot \sum_{i=3,4} b_{i+14} \cdot x_{i}+b_{19} \cdot x_{2} \cdot \prod_{i=2}^{4} x_{i} \\
& +\prod_{i=4,5} x_{i} \cdot \sum_{i=2}^{3} b_{i+18} \cdot x_{i}+b_{22} \cdot \prod_{i=1}^{4} x_{i}+\prod_{i=3}^{5} x_{i} \cdot \sum_{i=1}^{2} b_{i+22} \cdot x_{i}
\end{aligned}
$$

where $N B K G_{A t}$ - the level of national security of Kolmogorov-Gabor for Austria; 
$x_{1}$ - the share of duties on vehicles (based on fuel consumption) in the total amount of environmental taxes;

$x_{2}$ - the share of recurrent car taxes in the total amount of environmental taxes;

$x_{3}$ - the share of the tax on mineral oils in the total amount of environmental taxes;

$x_{4^{-}}$the share of road pricing for trucks for the use of highways in the total amount of environmental taxes;

$x_{5}$ - the share of the wastewater fee in the total amount of environmental taxes.

$$
\begin{aligned}
& N B K G_{F t}=f_{0}+\sum_{i=1}^{9} b_{i} \cdot x_{i}+x_{1} \cdot \sum_{i=2}^{9} b_{i+8} \cdot x_{i}+x_{2} \cdot \sum_{i=3}^{9} b_{i+15} \cdot x_{i}+x_{3} \\
& \cdot \sum_{i=4}^{9} b_{i+21} \cdot x_{i}+x_{4} \cdot \sum_{i=5}^{9} b_{i+25} \cdot x_{i}+b_{25} \cdot \prod_{i=1}^{3} x_{i}+\prod_{i=1,4} x_{i} \\
& \cdot \sum_{i=3,5} b_{i+23} \cdot x_{i}+\prod_{i=1,6} x_{i} \cdot \sum_{i=5,7} b_{i+25} \cdot x_{i}+\prod_{i=1,8} x_{i} \cdot \sum_{i=7,9} b_{i+27} \cdot x_{i}+\prod_{i=2,4} x_{i} \\
& \cdot \sum_{i=3,5} b_{i+29} \cdot x_{i}+\prod_{i=2,6} x_{i} \cdot \sum_{i=5,7} b_{i+31} \cdot x_{i}+\prod_{i=2,8} x_{i} \cdot \sum_{i=7,9} b_{i+33} \cdot x_{i}+\prod_{i=3,5} x_{i} \\
& \sum_{i=4,6} b_{i+35} \cdot x_{i}+\prod_{i=3,7} x_{i} \cdot \sum_{i=6,8} b_{i+37} \cdot x_{i}+b_{46} \cdot \prod_{i=3,8,9}^{3} x_{i}+\prod_{i=2,3,4} x_{i} \\
& \cdot \sum_{i=1,5} b_{i+46} \cdot x_{i}+\prod_{i=1,4,5} x_{i} \cdot \sum_{i=3,6} b_{i+46} \cdot x_{i}+\prod_{i=1,6,7} x_{i} \cdot \sum_{i=5,8} b_{i+45} \cdot x_{i} \\
& +\prod_{i=2,5,6} x_{i} \cdot \sum_{i=4,7} b_{i+49} \cdot x_{i}+\prod_{i=2,7,8} x_{i} \cdot \sum_{i=6,9} b_{i+49} \cdot x_{i}+b_{57} \cdot \prod_{i=1,7,8,9} x_{i} \\
& +\prod_{i=1,3,4,5} x_{i} \cdot \sum_{i=2,6} b_{i+56} \cdot x_{i}+\prod_{i=1,5,6,7} x_{i} \cdot \sum_{i=4,8} b_{i+56} \cdot x_{i}+b_{62} \cdot \prod_{i=1,6,7,8,9} x_{i} \\
& +\prod_{i=2,4,5,6} x_{i} \cdot \sum_{i=3,7} b_{i+60} \cdot x_{i}+\prod_{i=2,6,7,8} x_{i} \cdot \sum_{i=5,9} b_{i+60} \cdot x_{i}+\prod_{i=2}^{6} x_{i} \\
& \sum_{i=4,8} b_{i+62} \cdot x_{i}
\end{aligned}
$$$$
+\prod_{i=4}^{8} x_{i} \cdot \sum_{i=3,9} b_{i+65} \cdot x_{i}+\prod_{i=2}^{7} x_{i} \cdot\left(b_{70} \cdot x_{1}+b_{71} \cdot x_{8}+b_{72} \cdot x_{1} \cdot x_{9}\right)+b_{73} \cdot \prod_{i=3}^{9} x_{i}
$$

where $\quad N B K G_{F t}$ - the level of national security of Kolmogorov-Gabor for Finland; $x_{1}$ - the share of the fee for a fishing license in the total amount of environmental taxes; $x_{2}$ - the share of excise duty on fuel and electricity in the total amount of environmental taxes; $x_{3^{-}}$the share of the nuclear energy tax in the total amount of environmental taxes; $x_{4}$ - the share of the fee for oil losses in the total amount of environmental taxes; $x_{5}$ - the share of the registration fee for vehicles in the total amount of environmental taxes; $x_{6}$ - the share of vehicle tax in the total amount of environmental taxes; 
$x_{7^{-}}$the share of the fee for the collection / treatment of municipal waste in the total amount of environmental taxes;

$x_{8^{-}}$the share of the fee for nuclear waste in the total amount of environmental taxes;

$x_{9^{-}}$the share of fees for water use in the total amount of environmental taxes.

$$
\begin{aligned}
N B K G_{U K t}=f_{0} & +\sum_{i=1}^{4} b_{i} \cdot x_{i}+x_{1} \cdot \sum_{i=2}^{4} b_{i+3} \cdot x_{i}+x_{2} \cdot \sum_{i=3}^{4} b_{i+5} \cdot x_{i}+b_{10} \cdot \prod_{i=3}^{4} x_{i} \\
& +\prod_{i=1,2} x_{i} \cdot \sum_{i=3,4} b_{i+8} \cdot x_{i}+b_{13} \cdot \prod_{i=2}^{4} x_{i}+b_{14} \cdot \prod_{i=1}^{4} x_{i}
\end{aligned}
$$

where $\quad N B K G_{U K t}$ - the level of national security of Kolmogorov-Gabor for United Kingdom;

$x_{1}$ - the share of payment for passenger air transportation in the total amount of environmental taxes;

$x_{2}$ - the share of the fee for the license of the organizer of air transportation in the total amount of environmental taxes;

$x_{3}$ - the share of landfill tax in the total amount of environmental taxes;

$x_{4}$ - the share of renewable energy liabilities in the total amount of environmental taxes. 


\section{Annex B}

$$
\begin{aligned}
N B K G_{D t}=0,189 & +0,046 \cdot x_{1}+1.635 \cdot x_{2}-1.230 \cdot x_{3}+29.263 \cdot x_{4}-18.273 \cdot x_{5} \\
& +4.708 \cdot x_{1} \cdot x_{2}-60.235 \cdot x_{1} \cdot x_{3}-4559.195 \cdot x_{1} \cdot x_{4}+51.284 \cdot x_{1} \cdot x_{85} \\
& +77.079 \cdot x_{2} \cdot x_{3}+362.114 \cdot x_{2} \cdot x_{4}+73.115 \cdot x_{2} \cdot x_{5}+15137.190 \cdot x_{3} \\
& \cdot x_{4}+359.574 \cdot x_{3} \cdot x_{5}+1185.873 \cdot x_{4} \cdot x_{5}+716,484 \cdot x_{1} \cdot x_{2} \cdot x_{3} \\
& -356602,138 \cdot x_{1} \cdot x_{4} \cdot x_{3}-320256,943 \cdot x_{1} \cdot x_{4} \cdot x_{5}+124530,160 \cdot x_{4} \\
& \cdot x_{2} \cdot x_{3}+45475,906 \cdot x_{4} \cdot x_{2} \cdot x_{5}+1666511,259 \cdot x_{4} \cdot x_{5} \cdot x_{3} \\
& -1432823,059 \cdot x_{1} \cdot x_{2} \cdot x_{3} \cdot x_{4}+14314468,365 \cdot x_{5} \cdot x_{2} \cdot x_{3} \cdot x_{4} \\
& -14869402,174 \cdot x_{1} \cdot x_{5} \cdot x_{3} \cdot x_{4}
\end{aligned}
$$

where $\quad N B K G_{D t}$ - the level of national security of Kolmogorov-Gabor for Denmark;

$x_{1}$ - the share of the duty on coal in the total amount of environmental taxes;

$x_{2}$ - the share of the duty on electricity in the total amount of environmental taxes;

$x_{3}$ - the share of pesticide duties in the total amount of environmental taxes;

$x_{4}$ - the share of the duty on tires in the total amount of environmental taxes;

$x_{5}$ - the share of sale of vehicle number plates in the total amount of environmental taxes.

$$
\begin{aligned}
N B K G_{F r t}=0, & 393+114,760 \cdot x_{1} \cdot x_{2}+27,868 \cdot x_{2} \cdot x_{4}+2495,541 \cdot x_{1} \cdot x_{2} \cdot x_{3} \\
& -415343255,965 \cdot x_{1} \cdot x_{5} \cdot x_{6} \cdot x_{7}+0,629 \cdot x_{2}+13333,261 \cdot x_{5} \cdot x_{4} \\
& +14,722 \cdot x_{2} \cdot x_{3}-271,655 \cdot x_{6} \cdot x_{3}
\end{aligned}
$$

where $\quad N B K G_{F r t}$ - the level of national security of Kolmogorov-Gabor for France;

$x_{1}$ - the share of the CO2-related malus system for vehicle registration in the total amount of environmental taxes;

$x_{2}$ - the share of the contribution to electricity generators for public services they provide in the total amount of environmental taxes;

$x_{3^{-}}$the share of the internal tax on final consumption of electricity in the total amount of environmental taxes;

$x_{4}$ - the share of the internal tax on natural gas in the total amount of environmental taxes;

$x_{5}$ - the share of production taxes in the total amount of environmental taxes;

$x_{6}$ - the share of special fuel tax in foreign communities in the total amount of environmental taxes;

$x_{7}$ - the share of the tax on electricity pylons in the total amount of environmental taxes.

$$
\begin{aligned}
& N B K G_{A t}=0,474-0,414 \cdot x_{1}+0.497 \cdot x_{2}-0.334 \cdot x_{3}+0.582 \cdot x_{4}+1.087 \cdot x_{5}+0.986 \\
& \cdot x_{1} \cdot x_{2}-1.295 \cdot x_{1} \cdot x_{3}+1.263 \cdot x_{1} \cdot x_{4}+3.503 \cdot x_{1} \cdot x_{5}-0.007 \cdot x_{3} \cdot x_{2} \\
&+0.490 \cdot x_{4} \cdot x_{2}+0.441 \cdot x_{4} \cdot x_{2}+0.143 \cdot x_{3} \cdot x_{4}+0.110 \cdot x_{3} \cdot x_{5} \\
&+0.5805 \cdot x_{4} \cdot x_{5}-1.350 \cdot x_{1} \cdot x_{2} \cdot x_{3}-2.328 \cdot x_{1} \cdot x_{4} \cdot x_{3}-3.961 \cdot x_{1} \cdot x_{4} \\
& \cdot x_{5}-0.329 \cdot x_{4} \cdot x_{2} \cdot x_{3}-0.697 \cdot x_{4} \cdot x_{2} \cdot x_{5}-0.518 \cdot x_{4} \cdot x_{5} \cdot x_{3}-7.0033 \\
& \cdot x_{1} \cdot x_{2} \cdot x_{3} \cdot x_{4}-1.918 \cdot x_{5} \cdot x_{2} \cdot x_{3} \cdot x_{4}-10.046 \cdot x_{1} \cdot x_{5} \cdot x_{3} \cdot x_{4}
\end{aligned}
$$

where $N B K G_{A t}$ - the level of national security of Kolmogorov-Gabor for Austria; 
$x_{1}$ - the share of duties on vehicles (based on fuel consumption) in the total amount of environmental taxes;

$x_{2}$ - the share of recurrent car taxes in the total amount of environmental taxes;

$x_{3}$ - the share of the tax on mineral oils in the total amount of environmental taxes;

$x_{4^{-}}$the share of road pricing for trucks for the use of highways in the total amount of environmental taxes;

$x_{5}$ - the share of the wastewater fee in the total amount of environmental taxes.

$$
\begin{aligned}
N B K G_{F t}=4.460 & \cdot 10^{-1} \cdot x_{1}-3.351 \cdot 10^{1} \cdot x_{2}+4.401 \cdot 10^{-1} \cdot x_{3}-3.281 \cdot x_{4}-1.443 \\
& \cdot 10^{1} \cdot x_{5}-4.398 \cdot 10^{-1} \cdot x_{6}+7.166 \cdot 10^{-1} \cdot x_{7}+6.071 \cdot x_{8}-9.415 \cdot 10^{-1} \\
& \cdot x_{9}-1.658 \cdot 10^{1} \cdot x_{1} \cdot x_{2}+2.247 \cdot 10^{4} \cdot x_{1} \cdot x_{3}-6.401 \cdot 10^{3} \cdot x_{1} \cdot x_{4} \\
& -8.516 \cdot 10^{3} \cdot x_{1} \cdot x_{5}-3.342 \cdot 10^{2} \cdot x_{1} \cdot x_{6}-5.579 \cdot 10^{2} \cdot x_{1} \cdot x_{7}+1.036 \\
& \cdot 10^{2} \cdot x_{1} \cdot x_{8}-2.486 \cdot 10^{2} \cdot x_{1} \cdot x_{9}+\cdots
\end{aligned}
$$

where $\quad N B K G_{F t}$ - the level of national security of Kolmogorov-Gabor for Finland;

$x_{1}$ - the share of the fee for a fishing license in the total amount of environmental taxes;

$x_{2}$ - the share of excise duty on fuel and electricity in the total amount of environmental taxes;

$x_{3}$ - the share of the nuclear energy tax in the total amount of environmental taxes;

$x_{4}$ - the share of the fee for oil losses in the total amount of environmental taxes;

$x_{5}$ - the share of the registration fee for vehicles in the total amount of environmental taxes;

$x_{6}$ - the share of vehicle tax in the total amount of environmental taxes;

$x_{7}$ - the share of the fee for the collection / treatment of municipal waste in the total amount of environmental taxes;

$x_{8^{-}}$the share of the fee for nuclear waste in the total amount of environmental taxes;

$x_{9^{-}}$the share of fees for water use in the total amount of environmental taxes.

$$
\begin{aligned}
N B K G_{U K t}=0 & , 486+0,015 \cdot x_{1}-2,835 \cdot x_{2}+0,063 \cdot x_{3}+0,235 \cdot x_{4}+449,900 \cdot x_{1} \cdot x_{2} \\
& -36,278 \cdot x_{1} \cdot x_{3}+7,717 \cdot x_{1} \cdot x_{4}-821,175 \cdot x_{2} \cdot x_{3}+580,790 \cdot x_{2} \cdot x_{4} \\
& -9,235 \cdot x_{3} \cdot x_{4}+9823,818 \cdot x_{1} \cdot x_{2} \cdot x_{3}+163,213 \cdot x_{1} \cdot x_{4} \cdot x_{3} \\
& +21305,181 \cdot x_{4} \cdot x_{2} \cdot x_{3}+386203,880 \cdot x_{1} \cdot x_{2} \cdot x_{3} \cdot x_{4}
\end{aligned}
$$

where $\quad N B K G_{U K t}$ - the level of national security of Kolmogorov-Gabor for United Kingdom;

$x_{1}$ - the share of payment for passenger air transportation in the total amount of environmental taxes;

$x_{2}$ - the share of the fee for the license of the organizer of air transportation in the total amount of environmental taxes;

$x_{3}$ - the share of landfill tax in the total amount of environmental taxes;

$x_{4}$ - the share of renewable energy liabilities in the total amount of environmental taxes. 